\title{
Blood concentration of $\mathrm{GH}$ and leptin in developing Sarda goats*
}

\section{Carcangiu ${ }^{1}$, G.M. Vacca ${ }^{1}$, A. Parmeggiani' ${ }^{2}$, M.C. Mura ${ }^{1}$ and P.P. Bini'}

\author{
${ }^{1}$ Department of Animal Biology, Università degli Studi di Sassari \\ Via Vienna 2, 07100, Sassari, Italy \\ ${ }^{2}$ Department of Veterinary Morphophysiology and Animal Production, \\ Università degli Studi di Bologna \\ Via Tolara di Sopra 50, 40064 Ozzano dell'Emilia (BO), Italy
}

\begin{abstract}
In this research the blood levels of leptin, GH and glucose and its correlations with body weight, during the development of 20 Sardinian goat kids, was studied, from weaning up to the age of seven months. Blood levels of leptin and GH showed an increase $(\mathrm{P}<0.01)$ in relation to the rise of the animal's body weight and a decrease upon reaching $28 \mathrm{~kg}$. Leptin was found to positively correlate with GH and glucose and negatively correlate with weight. The variations of leptin ratios and their correlation with $\mathrm{GH}$ indicate an involvement of the lipidic hormone in regulating metabolism during development.
\end{abstract}

KEY WORDS: GH, leptin, goat, development

\section{INTRODUCTION}

In many domestic mammals the first period of life is represented by a very rapid body development. This physiological phase is under the control of diverse hormones but especially the somatotropic axis is playing a vital role (Gatford et al., 1997). Actually, the GH, by way of the IGF-I, is responsible for many actions, both direct and indirect, that determine the development of the animal. The pituitary secretion of GH declines with age (Thomas et al., 2000) and could be owed to the presence of circulating factors secreted from some of the body tissues that develop with age such as stored lipids (Delavaud et al., 2002). This last tissue being the one which synthesizes the leptin, one can hypothesize that the

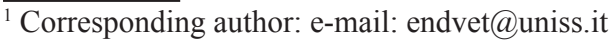


increase of the circulating blood levels of this molecule determine the decrease of the secretion of GH (Narro et al., 2003). Therefore, the objective of the present research is to study the relationship between GH and leptin in Sarda goats in the first eight months of life.

\section{MATERIAL AND METHODS}

Twenty young, female Sarda goats which were born of singular birth in the first days of December, were chosen. From weaning, which occurred at 35 days of age, the animals were raised separately and during the day went to a pasture of polyphytic grass and at night were kept in a goat pen where they were provided ad libitum access to concentrate feed, hay and water. The concentrate feed was consisted of $18 \%$ protein and gave $12.5 \mathrm{MJ}$ metabolizable energy $/ \mathrm{kg}$ dry matter. From the $50^{\text {th }}$ day to the $245^{\text {th }}$ day at 15 -day intervals, every animal had blood withdrawn from the jugular at 7:00 a.m. using a collection tubes with lithium heparin as anticoagulant. GH and leptin were measured with the RIA method (Gaiani and Mongiorgi, 1984; Multi Species RIA, Limco Research Inc., respectively) and glucose with colorimetric method (Sentinel, Milano). The data was submitted to analysis of variance and of correlations (Minitab ${ }^{\circledR}$ ).

\section{RESULTS}

Mean values of body weight, GH and leptin are reported in Table 1.

Table 1. Mean values ( \pm s.d.) of body weight, $\mathrm{GH}$ and leptin

\begin{tabular}{ccccc}
\hline Day & $\begin{array}{c}\text { Body weight } \\
\mathrm{kg}\end{array}$ & $\begin{array}{c}\mathrm{GH} \\
\mathrm{ng} / \mathrm{ml}\end{array}$ & $\begin{array}{c}\text { Leptin } \\
\mathrm{ng} / \mathrm{ml}\end{array}$ & $\begin{array}{c}\text { Glucose } \\
\mathrm{mg} / \mathrm{dl}\end{array}$ \\
\hline 50 & $15.3 \pm 1.9^{\mathrm{A}}$ & $5.1 \pm 2.5^{\mathrm{A}}$ & $1.8 \pm 0.3^{\mathrm{a}}$ & $62.6 \pm 8.5^{\mathrm{b}}$ \\
65 & $16.3 \pm 2.0^{\mathrm{A}}$ & $5.8 \pm 3.5^{\mathrm{A}}$ & $1.9 \pm 0.2^{\mathrm{a}}$ & $60.8 \pm 6.4^{\mathrm{b}}$ \\
80 & $16.9 \pm 2.5^{\mathrm{A}}$ & $6.2 \pm 3.9^{\mathrm{AB}}$ & $2.0 \pm 0.4^{\mathrm{ab}}$ & $60.2 \pm 6.8^{\mathrm{b}}$ \\
95 & $16.7 \pm 2.3^{\mathrm{A}}$ & $13.3 \pm 5.9^{\mathrm{C}}$ & $2.1 \pm 0.4^{\mathrm{b}}$ & $58.8 \pm 8.7^{\mathrm{b}}$ \\
110 & $18.1 \pm 2.5^{\mathrm{AB}}$ & $9.8 \pm 5.5^{\mathrm{B}}$ & $2.1 \pm 0.4^{\mathrm{b}}$ & $58.9 \pm 6.3^{\mathrm{b}}$ \\
125 & $19.7 \pm 2.4^{\mathrm{B}}$ & $7.1 \pm 2.2^{\mathrm{B}}$ & $2.0 \pm 0.3^{\mathrm{b}}$ & $59.2 \pm 7.9^{\mathrm{b}}$ \\
140 & $22.3 \pm 2.7^{\mathrm{C}}$ & $6.4 \pm 3.3^{\mathrm{B}}$ & $2.1 \pm 0.4^{\mathrm{b}}$ & $58.6 \pm 5.8^{\mathrm{b}}$ \\
155 & $22.7 \pm 2.8^{\mathrm{C}}$ & $6.5 \pm 3.2^{\mathrm{B}}$ & $1.9 \pm 0.3^{\mathrm{a}}$ & $56.4 \pm 9.2^{\mathrm{ab}}$ \\
170 & $24.2 \pm 2.6^{\mathrm{CD}}$ & $4.9 \pm 2.5^{\mathrm{A}}$ & $2.0 \pm 0.5^{\mathrm{ab}}$ & $54.4 \pm 6.4^{\mathrm{ab}}$ \\
185 & $26.0 \pm 2.8^{\mathrm{D}}$ & $4.5 \pm 2.5^{\mathrm{A}}$ & $1.8 \pm 0.2^{\mathrm{a}}$ & $55.1 \pm 5.4^{\mathrm{ab}}$ \\
200 & $27.1 \pm 3.0^{\mathrm{D}}$ & $3.4 \pm 1.9^{\mathrm{A}}$ & $1.8 \pm 0.3^{\mathrm{a}}$ & $49.6 \pm 6.7^{\mathrm{a}}$ \\
215 & $26.8 \pm 2.5^{\mathrm{D}}$ & $5.7 \pm 4.5^{\mathrm{A}}$ & $1.8 \pm 0.3^{\mathrm{a}}$ & $48.7 \pm 7.8^{\mathrm{a}}$ \\
230 & $26.8 \pm 2.9^{\mathrm{D}}$ & $5.8 \pm 4.2^{\mathrm{A}}$ & $1.8 \pm 0.3^{\mathrm{a}}$ & $50.1 \pm 5.1^{\mathrm{a}}$ \\
245 & $28.3 \pm 2.7^{\mathrm{D}}$ & $5.3 \pm 3.1^{\mathrm{AB}}$ & $1.7 \pm 0.3^{\mathrm{a}}$ & $51.34 \pm 6.4^{\mathrm{a}}$ \\
\hline
\end{tabular}

$\mathrm{A}, \mathrm{B}, \mathrm{C}, \mathrm{D}-\mathrm{P}<0.01 ;{ }^{\mathrm{a}, \mathrm{b}}-\mathrm{P}<0.05$ 
During the course of the observation the animals doubled in weight, beginning at around $15 \mathrm{~kg}$ and arriving at around $28 \mathrm{~kg}$ The biggest weight gain $(\mathrm{P}<0.01)$ was registered between 110 and 200 days, while in the last three surveys no weight gain were registered. The blood concentrations of GH gave evidence to growth at the $4^{\text {th }}$ sampling $(\mathrm{P}<0.01)$ and therefore just before the major weight gain. The leptin ratios showed larger values between the $4^{\text {th }}$ and the $8^{\text {th }}$ sampling $(\mathrm{P}<0.05)$. Glucose plasmatic concentration shows a decreasing trend with the highest values $(\mathrm{P}<0.05)$ at the beginning of the observations. Leptin resulted in a negative correlation with weight $(\mathrm{P}<0.01)$ and a positive correlation with $\mathrm{GH}$ $(\mathrm{P}<0.01)$. Glucose was correlated positively $(\mathrm{P}<0,01)$ with leptin and negatively $(\mathrm{P}<0,01)$ with body weight (Table 2$)$.

Table 2. Correlation coefficients ( $\mathrm{r}$ ) of the examined parameters

\begin{tabular}{lccc}
\hline & Leptin & GH & Glucose \\
\hline GH & $0.127^{* *}$ & & \\
Glucose & $0.243^{* *}$ & 0.324 & \\
Body weight & $-0.180^{* *}$ & $-0.270^{* * *}$ & $-0.251^{* *}$ \\
\hline
\end{tabular}

*** - $\mathrm{P}<0.001 ; * *$ - $\mathrm{P}<0.01$

\section{DISCUSSION}

The body weight attained at eight months by our goats was similar to the normally of this breed at this age. GH blood level showed not a decreasing trend as observed in lambs by Klindt et al. (1985). Instead, in the present study the peak was showed around the $3^{\text {rd }}$ month of life just before the goats displayed the most rapid growth. Many factors influence the GH secretion as feeding, environmental factors and some hormones. The goats were allowed ad libitum access to feed in the present study and the feeding was not changed during the course of the work. In addition the climate at our latitude is mild, consequently we don't believe that feeding or climatic changes caused the GH to peak around 95 to 110 days. Oestrogens increase GH during oestrous, but this was apparently neither the cause of the GH peak in the present because the animals were in the prepubertal age (Gluckman et al., 1987). Our hypothesis is that the GH peak triggers the growth process both directly and through the release of growth factors as IGF. The increase in stored body fat produces an increase in blood leptin concentrations (Daniel et al., 2002; Delavaud et al., 2002). Also with growth, an increased disposition of subcutaneous fat is observed mainly at the end of the body development and thus an increase in the secretion of leptin (Ehrhardt et al., 2000). Our findings are not in agreement with the findings of this last author because the increase in plasmatic leptin was registered only at the moment of maximum development and there was no continuous with age. Furthermore, the highest values of leptin coincided with 
the highest levels of GH, which suggests a link between these two molecules. This correlation, however, agrees with what was reported by McMahon et al. (2001) that leptin works at the level of the arcuate nucleus in the hypothalamus, where receptors are present for this hormone, stimulating the secretion of GH by way of the inhibition of the somatostatin.

\section{CONCLUSIONS}

The reported data show how GH and leptin are involved in body development but some mechanism stills remains to be clarified. We suggest that the GH peak observed before body weight increase triggers this complicated process and that leptin rise during growth influences lipid metabolism. However these hypotheses remain to be elucidated.

\section{REFERENCES}

Delavaud C., Ferlay A., Faulconnier Y., Bocquier F., Kann G., Chilliard Y., 2002. Plasma leptin concentration in adult cattle: effects of breed, adiposity, feeding level, and meal intake. J. Anim. Sci. 80, 1317-1328

Daniel J.A., Whitlock B.K., Baker J.A., Steele B., Morrison C.D., Keisler D.H., Sartin J.L., 2002. Effect of body fat mass and nutritional status on 24-hour leptin profiles in ewes. J. Anim. Sci. 80, 1083-1089

Ehrhardt R.A., Slepetis R.M., Siegal-Willott J., Van Amburgh M.E., Bell A.W., Boiscalair Y.R., 2000. Development of specific radioimmunassay to measure physiological changes of circulating leptin in the cattle and sheep. J. Endocrinol. 166, 519-528

Gaiani R., Mongiorgi S., 1984. GH, PRL and insulin variation in lactating goats. In: Proceeding of Annual Meeting Società Italiana delle Scienze Veterinarie XLI, 269-273

Gatford K.L., Quinn K.J., Walton P.E., Grant P.A., Hosking B.J., Egan A.R., Owens P.C., 1997. Ontogrnic and nutritional changes in circulating insulin-like growth factor (IGF)-I, IGF-II and IGF-binding proteins in growing ewe and ram lambs. J. Endocrinol. 155, 47-54

Gluckman P.D., Breier B.H., Davis S.R., 1987. Physiology of the somatotropic axis with particular reference to the ruminant. J. Dairy Sci. 70, 442-466

Klindt J., Ohlson D.L., Davis S.L., Schanbacher B.D., 1985. Ontogeny of growth hormone, prolactin, luteinizing hormone, and testosterone secretory patterns in the ram. Biol. Reprod. 33, 236-244

McMahon C.D., Radcliff R.P., Lookingland K.J., Tucker H.A., 2001. Neuroregulation of growth hormone secretion in domestic animals. Domest. Anim. Endocrinol. 20, 65-87

Narro L.A., Thomas M.G., Silver G.A., Rozeebon K.J., Keisler D.H., 2003. Body composition, leptin, and the leptin receptor and their relationship to the growth hormone (GH) axis in growing wethers treated with zeranol. Domest. Anim. Reprod. 24, 243-255

Thomas M.G., Carroll J.A., Raymond S.R., Matteri R.L., Keisler D.H., 2000. Transcriptional regulation of pituitary synthesis and secretion of growth hormone in growing wethers and the influence of zeranol on these mechanisms. Domest. Amim. Endocrinol. 18, 309-324 